\title{
Mechanical Cervical Ripening with Foley Catheter Balloon: Rekindling a Forgotten Art
}

\author{
${ }^{1}$ Neema Acharya, ${ }^{2}$ Amruta Gadge, ${ }^{3}$ Mohit Agrawal, ${ }^{4}$ Monisha Singh
}

\section{ABSTRACT}

Introduction: Induction of labor is carried out in $20 \%$ of pregnancies in some countries. The success of induction of labor depends mainly upon the cervical ripening score. The most popularly used prostaglandins, misoprostol and dinoprostone, are effective in cervical ripening but have side effects of uterine hyperstimulation and fetal hypoxia, which may increase operative intervention and admissions to neonatal intensive care units. Mechanical dilatation is an age-old method that is safe and effective but lost its popularity with fear of chorioamnionitis.

Aims and objectives: To study the efficacy and safety of Foley's catheter balloon as cervical ripening method when compared with misoprostol administered vaginally.

Materials and methods: In this experimental study, 50 full-term patients with poor cervical score were included. They were divided into group L - those who received intracervical Foley and group II-those who received vaginal misoprostol. The cervical score was reassessed 24 hours later. Other variables like mode of delivery, fetal heart variability, and uterine hyperstimulation were also studied.

Results: Both groups I and II showed improvement in cervical score. The occurrence of uterine hyperstimulation and fetal heart variabilities was less in group I.

Conclusion: Mechanical cervical ripening with Foley's balloon catheter is as effective and safer compared with msoprostol when used for preinduction cervical ripening in full-term patients.

Keywords: Foley's catheter, Mechanical cervical ripening, Misoprostol.

How to cite this article: Acharya N, Gadge A, Agrawal M, Singh M. Mechanical Cervical Ripening with Foley Catheter Balloon: Rekindling a Forgotten Art. J South Asian Feder Obst Gynae 2018;10(1):1-4

Source of support: Nil

Conflict of interest: None

Date of received: 15 January 2018

Date of acceptance: 25 February 2018

Date of publication: May 2018

${ }^{1}$ Professor, ${ }^{2-4}$ Junior Resident

${ }^{1-4}$ Department of Obstetrics and Gynecology, Datta Meghe Institute of Medical Sciences, Wardha, Maharashtra, India

Corresponding Author: Neema Acharya, Professor, Department of Obstetrics and Gynecology, Datta Meghe Institute of Medical Sciences, Wardha, Maharashtra, India, e-mail: neemasacharya@ gmail.com

\section{INTRODUCTION}

Induction of labor is carried out in $20 \%$ of pregnancies in some countries. ${ }^{1}$ It is indicated when interrupting the pregnancy is advantageous for mother or baby, where it has been shown to decrease perinatal and maternal morbidity and mortality. The cervical score determines the success of induction of labor. Most commonly used cervical ripening agents are misoprostol and dinoprostone. The main disadvantage of prostaglandins is the associated uterine hyperstimulation (3-20\%), affecting fetal heart rate and thus contributing to a risk factor for fetal hypoxia and thereby operative intervention. ${ }^{2}$ The advantage of the prostaglandin analogs is that it carries out ripening of the cervix in an unfavorable cervix of Bishop score (BS) less than 6 . This is due to the relation between cervix ripening and myometrium-stimulating effects. ${ }^{3}$ Cervical ripening is a process leading to partial cervical effacement and dilatation due to physical dilatation of cervix.

Mechanical cervical dilatation is an age-old method that was used routinely. Due to fear of introducing infections and availability of newer safer drugs, it is not preferred. ${ }^{1}$ The transcervical balloon catheter is a method that is used as an alternative to prostaglandins for labor induction but due to fear of introducing infection and proven efficacy of prostaglandins, it has not been used extensively. But Foley's catheter is as effective as prostaglandins, decreasing the risk of infection to the mother and child. ${ }^{4}$ Catheter induction requires less intrapartum supervision compared with prostaglandins. Newly published PROBAAT trial suggests that a mechanical approach to induction of labor is associated with fewer complications. ${ }^{5}$ Hence, the aim of this study is to analyze the effect of this method on cervical ripening when compared with misoprostol.

\section{AIM}

To study the effectiveness and safety of Foley's catheter for cervical ripening before induction of labor in term pregnancies as compared with misoprostol and to study the mode of delivery and occurrence of maternal and neonatal complications in both groups. 


\section{MATERIALS AND METHODS}

This was a pilot study done at a tertiary rural care center for a duration of 6 months from January 2016 to June 2016. Total 50 low-risk primigravida patients requiring induction of labor at term having poor cervical score were included. High-risk pregnancies were excluded. It was a double-blind study. Patients were randomized into group I (Foley's catheter) and group II (misoprostol) by closed envelope method. Group I patients had intracervical Foley's catheter no. F16 with a balloon filled with $30 \mathrm{cc}$, while group II patients had misoprostol $25 \mu \mathrm{g}$ for two doses 6 hours apart given vaginally under all aseptic precautions ( 25 women in each group). Bishop's score was recorded pre- and post- 24 hours of intervention. Foley's catheter, if not expelled out spontaneously, was removed after 24 hours. Intrauterine infection was reported if there was any maternal febrile morbidity during the study period. Oxytocin was used for further induction or augmentation of labor if needed. Cervical ripening score (Bishop's score pre- and 24 hours postintervention, duration of labor parameters, uterine hypertonus, and neonatal outcome were the variables studied.

\section{Statistical Analysis}

Statistical analysis was done by using Statistical Package for the Social Sciences version 17.0 and descriptive and interferential statistics using Student's t-test and Chi square test was applied to compare these variables among groups and $p<0.05$ was considered as level of significance.

\section{DISCUSSION}

As shown in Table 1, there was a significant change in Bishop's score at the end of 24 hours. In group I, the mean Bishop's score changed from 1.8 to $7.16(p=0.0001)$, while in group II, it changed from 1.64 to $6.8(\mathrm{p}=0.0001)$. Hence, in the present study, it indicates that both the methods are equally effective in improving the cervical score. It is in accordance with the study done by Adeniji et $\mathrm{al}^{6}$ who concluded that intravaginal misoprostol is as effective a preinduction cervical ripening agent as transcervical Foley catheter. Also, in a study done by Prager et al, ${ }^{7}$ the authors concluded that transcervical Balloon catheter can be used to achieve effective and safe preinduction cervical ripening of cervices like misoprostol and both are effective and safe.

Table 2 shows the duration of induction to the active phase of labor was comparable in both groups. There was no significant difference between the two $(p=0.187)$. Also, the mean duration of active phase of labor (Table 3) in group I was 7.04 hours, while in group II it was 6.28 . The difference was statistically significant (0.0001) this may be due to the additional effect of misoprostol on the uterine contractility. This is in agreement with the study done by Afolabi et al, ${ }^{10}$ which showed that misoprostol in terms of induction to delivery interval is more efficacious than intracervical insertion of Foley catheter for cervical ripening and induction of labor.

As shown in Table 4 the duration of the second stage of labor in both groups I and II was comparable since there was no significant statistical difference

Table 1: Comparison of primary BS and postinduction BS in two groups using Student's paired t-test

\begin{tabular}{lllllll}
\hline \multirow{2}{*}{ Groups } & & & $\begin{array}{l}\text { Standard } \\
\text { deviation }\end{array}$ & $\begin{array}{l}\text { Standard error } \\
\text { mean }\end{array}$ & $t$-value & $p$-value \\
\hline I & Primary BS & 1.80 & 25 & 0.40 & 0.08 & 42.02 \\
& Postinduction BS & 7.16 & 25 & 0.37 & 0.07 & \\
II & Primary BS & 1.64 & 25 & 0.48 & $0.0001, \mathrm{~S}$ \\
& Postinduction BS & 6.80 & 25 & 0.50 & 0.10 & 32.25 \\
& & &
\end{tabular}

S: Significant

Table 2: Comparison of induction to active phase time in two groups

\begin{tabular}{llllllll}
\hline & & & & Standard & Standard error \\
& Groups & $n$ & Mean & deviation & mean & $t$-value & $p$-value \\
\hline Induction to active phase time & $\mathrm{I}$ & 25 & 5.01 & 0.04 & 0.008 & 1.33 & $0.187, \mathrm{NS}$ \\
& $\mathrm{II}$ & 25 & 4.79 & 0.80 & 0.161 & & \\
\hline
\end{tabular}

NS: Not significant

Table 3: Comparison of length of active phase of labor (in hours) in two groups

\begin{tabular}{|c|c|c|c|c|c|c|c|}
\hline & Groups & $n$ & Mean & $\begin{array}{l}\text { Standard } \\
\text { deviation }\end{array}$ & $\begin{array}{l}\text { Standard error } \\
\text { mean }\end{array}$ & $t$-value & $p$-value \\
\hline \multirow[t]{2}{*}{ Length of active phase of labor } & $\mathrm{I}$ & 25 & 7.04 & 0.20 & 0.04 & 7.60 & $0.0001, \mathrm{~S}$ \\
\hline & II & 25 & 6.28 & 0.45 & 0.09 & & \\
\hline
\end{tabular}

S: Significant 
Mechanical Cervical Ripening with Foley Catheter Balloon

Table 4: Comparison of length of second stage of labor (in minutes) in two groups

\begin{tabular}{|c|c|c|c|c|c|c|c|}
\hline & Groups & $n$ & Mean & $\begin{array}{l}\text { Standard } \\
\text { deviation }\end{array}$ & $\begin{array}{l}\text { Standard error } \\
\text { mean }\end{array}$ & $t$-value & $p$-value \\
\hline \multirow[t]{2}{*}{ Length of second phase of labor } & I & 25 & 44.80 & 2.69 & 0.53 & 0 & $1.00, \mathrm{NS}$ \\
\hline & II & 25 & 44.80 & 2.69 & 0.53 & & \\
\hline
\end{tabular}

NS: Not significant

Table 5: Comparison of mode of delivery in two groups

\begin{tabular}{lllll}
\hline & Group I & Group II & $\chi^{2}$-value & p-value \\
\hline Cesarean section & $9(36 \%)$ & $13(52 \%)$ & 2.06 & $0.356, \mathrm{NS}$ \\
Instrumental vaginal & $1(4 \%)$ & $2(8 \%)$ & & \\
Spontaneous vaginal & $15(60 \%)$ & $10(40 \%)$ & & \\
\hline
\end{tabular}

NS: Not significant

Table 7: Number of cases with uterine hypertonus in each group

\begin{tabular}{lllll}
\hline Hypertonus & Group I & Group II & $\chi^{2}$-value & p-value \\
\hline Yes & $0(0)$ & $4(56 \%)$ & & \\
No & $25(68 \%)$ & $21(44 \%)$ & & \\
\hline Total & $25(100 \%)$ & $25(100 \%)$ & & \\
\hline
\end{tabular}

between the two $(p=1.00)$. Similar results were found by Owolabi et al. ${ }^{5}$

In our study, there was no significant statistical difference in the mode of delivery. The number of cesarean sections, instrumental deliveries, and spontaneous vaginal deliveries was comparable in both the groups as shown in Table 5 . While the study by Rozenberg et $\mathrm{l}^{8}$ demonstrated that the rate of cesarean section performed for acute fetal distress was higher with use of misoprostol, Barrilleaux et $\mathrm{al}^{9}$ compared oral misoprostol with Foley catheter and did not report a significant difference between the two groups in view of the rate of instrumental vaginal delivery as seen in the present study.

As depicted in Table 6, 14 babies had low Apgar score at 1 and 5 minutes, requiring neonatal intensive care unit (NICU) care in group II (56\%) as compared with 8 in group I (32\%). This was statistically significant.

This is similar to the findings of a study by Afolabi et $\mathrm{al}^{10}$ which showed that neonates requiring NICU admissions were more in misoprostol group.

As shown in Table 7, four cases of uterine hypertonus were noted in misoprostol group II, while there was no such case found in group I. Similar findings were found by Farah Ziyauddin, ${ }^{1}$ Seema Hakim, ${ }^{2}$ and Sridevi Beriwa when they compared foleys with prostglandin for cervical ripening. ${ }^{11}$ There was not a single case of febrile morbidity or chorioamnionitis in both groups.

\section{LIMITATIONS OF THE STUDY}

The sample size was small and we did not include highrisk pregnancies.
Table 6: Comparison of low APGAR score and NICU admission in two groups

\begin{tabular}{lllll}
\hline NICU admission & Group I & Group II & $\chi^{2}$-value & $p$-value \\
\hline Yes & $8(32 \%)$ & $14(56 \%)$ & 2.92 & 0.008, NS \\
No & $17(68 \%)$ & $11(44 \%)$ & & \\
\hline Total & $25(100 \%)$ & $25(100 \%)$ & & \\
\hline NS: Not significant
\end{tabular}

\section{CONCLUSION}

Mechanical cervical dilatation with Foley's catheter balloon is as effective as misoprostol for cervical ripening. The NICU admissions and cesarean delivery rate were lesser in group I compared with group II, though not statistically significant. It should be used more for cervical ripening before induction of labor at term as it is easily available, safe, and does not affect the mode of delivery and fetal outcome. Unlike misoprostol, Foley catheter-induced mechanical cervical ripening is not associated with hypertonus of the uterus. This added advantage can be utilized while inducing high-risk cases with previous uterine scar.

\section{REFERENCES}

1. Heinemann J, Gillen G, Sanchez-Ramos L, Kaunitz AM. Do mechanical methods of cervical ripening increase infectious morbidity? A systematic review. Am J Obstet Gynecol 2008 Aug;199(2):177-187.

2. National Institute for Clinical Excellence. Clinical guidelines for induction of labor, Appendix-E. London: NICE; 2001.

3. Yates J. Foley's catheter is as effective as prostaglandins for induction of labour. OBG Manag 2011 Nov;23(11).

4. St Onge RD, Connors GT. Preinduction cervical ripening: a comparison of intracervical PGE2 gel versus the Foley catheter. Am J Obstet Gynecol 1995 Feb;172(2 Pt 1): 687-690.

5. Owolabi AT, Kuti O, Ogunlola IO. Randomised trial of intravaginal misoprostol and intracervical Foley catheter for cervical ripening and induction of labour. J Obstet Gynaecol 2005 Aug;25(6):565-568.

6. AdenijiOA, Oladokun A, OlayemiO,AdenijiOI,OdukogbeAA, Ogunbode O, Aimakhu CO, Omigbodun AO, Ilesanmi AO. Pre-induction cervical ripening: transcervical Foley catheter versus intravaginal misoprostol. J Obstet Gynaecol 2005 Feb;25(2):134-139.

7. Prager M, Eneroth-Grimfors E, Edlund M, Marions L. A randomised controlled trial of intravaginal dinoprostone, intravaginal misoprostol and transcervical balloon catheter for labour induction. BJOG 2008 Oct;115(11):1443-1145.

8. Rozenberg P, Chevret S, Goffinet F, Durand-Zaleski I, Ville Y, Vayssiière C, Roberto A, Lahna Z, Nisand I, Fisch C, et al. 
Induction of labour with a viable infant: a randomised clinical trial comparing intravaginal misoprostol and intravaginal dinoprostone. Br J Obstet Gynaecol 2001 Dec;108(12):1255-1262.

9. Barrilleaux PS, Bofill JA, Terrone DA, Magann EF, May WL, Morrison JC. Cervical ripening and induction of labor with misoprostol, dinoprostone gel, and a Foley catheter: a randomized trial of 3 techniques. Am J Obstet Gynecol 2002 Jun;186(6):1124-1129.
10. Afolabi BB, Oyeneyin OL, Ogedengbe OK. Intravaginal misoprostol versus Foley catheter for cervical ripening and induction of labor. Int J Gynaecol Obstet 2005 Jun;89(3): 263-267.

11. Ziyauddin F, Hakim S, Beriwal S. The transcervical Foley catheter versus the vaginal prostaglandin $\mathrm{E} 2 \mathrm{gel}$ in the induction of labour in a previous one caesarean section-a clinical study. J Clin Diagn Res 2013 Jan; 7(1):140-143. 